\title{
Regenerative bioturbation by intertidal burrowing crabs modifies microphytobenthic composition and enhances primary production in SW Atlantic mudflats
}

\author{
Micaela Giorgini ${ }^{1, *}$, Ana Miguez ${ }^{1}$, K. Soledad Esquius ${ }^{2}$, Clara Diaz de Astarloa ${ }^{1}$, \\ Oscar Iribarne $^{1}$, Eugenia Fanjul ${ }^{1}$, Mauricio Escapa ${ }^{1}$ \\ ${ }^{1}$ Laboratorio de Ecología, ${ }^{2}$ Laboratorio de Limnología, Instituto de Investigaciones Marinas y Costeras (IIMyC), \\ UNMdP - CONICET, Mar del Plata, CP 7600, Argentina
}

\begin{abstract}
In coastal systems, benthic microalgae are important primary producers that significantly contribute to global primary production. Microphytobenthic (MPB) community structure and the ecosystem functions that it mediates are modulated by biotic and abiotic factors. Through burrowing activity, different types of bioturbators can impact MPB in different ways. Through directed sampling and field experiments performed at the Mar Chiquita coastal lagoon (Argentina), we evaluated the effect of regenerative bioturbation (continuous digging and maintenance of burrows, with sediment transfer from depth to surface) by the intertidal burrowing crab Neohelice (Chasmagnatus) granulata on MPB. We compared sediment properties and MPB attributes between natural burrowed and non-burrowed areas. Moreover, we experimentally manipulated regenerative bioturbation to evaluate if MPB composition and primary production are altered by crab burrowing activity. Field sampling showed that MPB and sediment properties differed between natural burrowed and non-burrowed areas. Experimental results indicated that regenerative bioturbation by $N$. granulata increased sediment oxygen concentration at each measured depth and also changed MPB composition (due to the reduced total abundance of cyanobacteria), but nearly doubled primary production in comparison with plots without bioturbation. Thus, the net effects of regenerative bioturbation were positive for MPB productivity, reinforcing the idea that this kind of bioturbation is an important biological force that enhances primary production in intertidal systems.
\end{abstract}

KEY WORDS: Regenerative bioturbation $\cdot$ Microphytobenthos $\cdot$ Burrowing crab $\cdot$ Neohelice (Chasmagnatus) granulata $\cdot$ Intertidal sediments

\section{INTRODUCTION}

Microphytobenthic (MPB) communities consist of photoautotrophic microorganisms, mainly diatoms, cyanobacteria, flagellates and green algae, that live in and on subtidal and intertidal sediments where light reaches the sediment surface (Underwood 2001).
These communities play an important role in key ecosystem functions, such as primary production, sediment stabilization and biogeochemical cycling (Middelburg et al. 2000). MPB cover large areas and have high areal productivity rates (Heip et al. 1995, MacIntyre et al. 1996). Indeed, at the top 1-2 mm of the sediment, benthic microalgae can achieve similar 
areal productivity rates as phytoplankton in the overlying water column (Underwood \& Kromkamp 1999), and may contribute up to $50 \%$ of estuarine primary production (e.g. northern Adriatic coasts, Blackford 2002; Colne estuary, UK, Underwood et al. 2005). MPB stabilize the sediment surface due to the extrusion of extracellular polymeric substances (Underwood et al. 2005). These molecules form a network that traps and binds sediment particles, increasing sediment cohesion and stability (de Brouwer et al. 2002, Stal 2010). MPB can also modulate benthic biogeochemical processes, such as denitrification, nitrification and $\mathrm{N}_{2}$ fixation (Sundbäck et al. 2004, Stutes et al. 2006). These processes are fundamental for intertidal system functioning, and in tidal flats their dynamics are regulated by different attributes of MPB such as composition, functional diversity, species richness, abundance and evenness (Thrush et al. 2017).

The composition of phototrophic communities is determinant for coastal ecosystem dynamics (Duarte 1995). MPB productivity is the consequence of the different responses to irradiance of its constituent taxa (Underwood et al. 2005). The exposure to high irradiance levels can limit MPB productivity (Serôdio et al. 2008). MPB dominated by diatoms are tolerant to high light intensities due to physiological strategies (developed by epipsammic and epipelic diatoms) and behavioral strategies (developed only by epipelic diatoms), so photoinhibition is apparently absent when the biofilm as a whole is measured (Serôdio 2004), thus ensuring high and constant levels of production (Mouget et al. 2008). As for many kinds of communities, composition also influences sediment biogeochemical cycles via species traits (Tilman 1999). MPB dominated by cyanobacteria increase sulfide oxidation and nitrogen fixation in the surrounding environment (e.g. Janousek 2009), while those dominated by diatoms usually show high rates of inorganic nitrogen consumption (i.e. ammonia and nitrate) and oxygen production (Nilsson \& Sundbäck 1996). MPB structure is also influenced by abiotic and biotic interactions (Kristensen 2007). For example, the microscale distribution of sediment particles of varying sizes can directly influence diversity (Paterson \& Hagerthey 2001), and factors like temperature, desiccation and salinity also determine composition, as they differently affect the success of each taxonomic group (Underwood \& Provot 2000). Herbivory and bioturbation are important biotic factors that influence MPB growth and development (Admiraal 1984, Needham et al. 2011). Benthic macrofauna present a wide range of strategies related to their movement and feeding behavior, so their impact on MPB is very variable (Waldbusser et al. 2004). While some studies have shown that deposit feeding organisms may decrease MPB abundance due to grazing, others have shown that sediment reworking during feeding activities has a positive effect on MPB (e.g. Armitage et al. 2009, Sandwell et al. 2009).

Bioturbation by benthic macrofauna is widely recognized as a key ecological process due to its effect on ecosystem functioning in coastal and marine habitats (Teal et al. 2013). It is defined as all types of transport processes carried out by organisms that directly or indirectly affect sediment matrices, including sediment reworking and burrow ventilation (Kristensen et al. 2012). Bioturbation affects sediment properties such as sedimentary oxygen concentration, pH and redox gradients (Daleo et al. 2007, Queirós et al. 2015), permeability, organic matter subduction (Lohrer et al. 2004, Fanjul et al. 2015), $\mathrm{NH}_{4}{ }^{+}$release (Emmerson et al. 2001, Biles et al. 2002) and grain size distribution (Escapa et al. 2007). Moreover, bioturbation can affect macrofaunal community structure (Volkenborn et al. 2007, Alvarez et al. 2013), as well as bacterial abundance, composition and activity (Bertics \& Ziebis 2009, Gilbertson et al. 2012). Bioturbators also regulate carbon (Kristensen 2001) and nitrogen cycles (Bertics et al. 2010, Fanjul et al. 2011) due to the alteration of the physico-chemical environment that affects bacterial assemblages (Laverock et al. 2011). MPB primary production is favored by the presence of diverse and abundant macrobenthic bioturbators, indicating complex feedbacks and interactions (Lohrer et al. 2004, 2010).

Although much information is available about the role of some bioturbation modes, such as the upward/ downward conveyors and biodiffusers, the role of regenerative bioturbation remains relatively unexplored (but see Escapa et al. 2008, Wang et al. 2010, Needham et al. 2011, 2013, Alberti et al. 2015, Fanjul et al. 2015). Regenerative bioturbators dig and continuously maintain burrows, thereby transferring large amounts of deep sediment to the surface. Their burrows also enhance sediment trapping (Botto et al. 2006, Escapa et al. 2008) and are passively irrigated, which contrasts with the active burrow irrigation that characterizes other bioturbation modes (Kristensen et al. 2012). Regenerative bioturbation is typically exerted by burrowing crustaceans such as burrowing crabs that inhabit saltmarsh and mangrove sediments (Kristensen et al. 2012). Their burrowing activities increase the potential for biological and chemical exchange by increasing the area of sediment-water/ air interface between 150 and 380\% (Kristensen 
2008). New Zealand estuaries, for example, are inhabited by the regenerative bioturbator crab Austrohelice crassa, a key species in the regulation of ecosystem functioning (Needham et al. 2013). In Chinese salt marshes, the burrowing crabs Helice tridens tientsinensis, Sesarma dehaani, S. plicata and UCa arcuata dominate the macrofauna, constructing burrows with high morphological variation that strongly affect the flow of energy and materials (Wang et al. 2010). Mangrove sediments also show high rates of regenerative bioturbation, mainly by sesarmid crabs (e.g. Neoepisesarma versicolor, S. messa) and fiddler crabs (e.g. U. pugilator, U. pugnax, U. vocans, $U$. annulipes), which affect sediment biogeochemistry and microbial activity (Kristensen 2008).

The intertidal burrowing crab Neohelice (Chasmagnathus) granulata (up to $40 \mathrm{~mm}$ carapace width) is one of the most abundant benthic macroinvertebrates in southwest Atlantic (SWA) protected softbottom intertidal systems (Iribarne et al. 1997). This crab has long been considered to be an allogenic ecosystem engineer (sensu Jones et al. 1996) because it modifies the physical and chemical sedimentary environment, thus affecting resource availability to co-inhabitant species (e.g. polychaetes: Escapa et al. 2004; fishes: Martinetto et al. 2005; birds: Iribarne et al. 2005; plants: Daleo \& Iribarne 2009; snails: Alvarez et al. 2013). This species can remove up to $2.4 \mathrm{~kg}$ $\mathrm{m}^{-2} \mathrm{~d}^{-1}$ of salt marsh sediment and up to $6 \mathrm{~kg} \mathrm{~m}^{-2} \mathrm{~d}^{-1}$ in mudflats (Iribarne et al. 1997, Botto \& Iribarne 2000) as a result of burrow excavation and maintenance, which includes sediment removal and transport from depth to the surface and also passive trapping of sediment into open burrows (Botto \& Iribarne 2000, Escapa et al. 2008). This crab needs to remove large amounts of sediment in order to maintain large burrows (up to $17 \mathrm{~cm}$ width and $1 \mathrm{~m}$ depth), thus promoting high rates of regenerative bioturbation (sensu Kristensen et al. 2012). This activity modifies the sedimentary matrix through geochemical alterations and also changes grain size distribution (Escapa et al. 2007), sediment water content (Bortolus \& Iribarne 1999), organic matter content and inorganic nutrient availability (Fanjul et al. 2007, 2011). Given that these factors are known to affect MPB (Underwood 2001), we expect an indirect impact of regenerative bioturbation on MPB as a result of modifying the sedimentary environment.

In this study, we investigated the effects of regenerative bioturbation by $N$. granulata on MPB abundance/diversity/composition and the possible impact on intertidal MPB-mediated ecosystem functions, such as primary production. Given the high bioturba- tion intensity of $N$. granulata, we expected that it would affect MPB.

\section{MATERIALS AND METHODS}

\subsection{Study site}

The study was carried out between February 2014 and February 2015 at intertidal mudflats in the Mar Chiquita coastal lagoon (Argentina, 37 $32^{\prime} \mathrm{S}, 57^{\circ} 19^{\prime}$ $\mathrm{W})$. This site is the southernmost in a series of temperate coastal lagoons along the SWA coast (Perillo 1995) and is dominated by a semidiurnal microtidal regime (tidal amplitude $<1 \mathrm{~m}$ ), with low current velocities (mean: $5.4 \mathrm{~cm} \mathrm{~s}^{-1}$; Iribarne \& Botto 1998) and highly variable salinity (from 0.5 to 34 ; Reta et al. 2001). In this coastal lagoon, the high intertidal zones are characterized by the presence of salt marshes vegetated by Sporobolus densiflorus (Spartina densiflora), while bare mudflats are found in the lower intertidal zones (Iribarne et al. 1997), and its sediments are mostly composed of fine sands, silts and clays.

Within these sediments, MPB is mainly composed of diatoms and cyanobacteria, while euglenophytes and chlorophytes are present in lower proportions (Alvarez et al. 2013, Alberti et al. 2017). These intertidal flats (i.e. saltmarshes and mudflats) are also inhabited by the burrowing crab Neohelice granulata (Iribarne et al. 1997, Luppi et al. 2002). This species is active year round (primarily from early spring to late autumn) and can excavate substrates over a wide range of environmental conditions (e.g. from hypersaline to brackish water conditions) and sedimentary contexts (from muddy sediments dominated by silts and clay to sandy and even gravelly sandy sediments). Thus, $N$. granulata can withstand a high range of environmental variability through physiological adaptations and without affecting its burrowing activity (Halperin et al. 2000, Luppi et al. 2013). Locally, the burrows can be found from the lowest areas of mudflats to the highest areas of salt marshes, but crab burrowing activity is concentrated at marsh-mudflat edges where higher burrow densities are generally registered (Spivak et al. 1994, Iribarne et al. 2005, Mendez Casariego et al. 2011). When crabs inhabit salt marshes, they behave as herbivores, feeding mainly on Sporobolus spp., and their burrowing activity is facilitated by marsh plants (Bortolus et al. 2002), thus generating areas of high burrow density below plant canopies. However, crabs inhabiting mudflats change their trophic mode to 
deposit feeding (Botto et al. 2005, Alberti et al. 2011), and their burrowing activity is concentrated in patches that exhibit high variation both in areal extent and temporal stability (Botto \& Iribarne 1999, Iribarne et al. 2005). This is partially explained by the high mobility rate among patches in short periods (Luppi et al. 2013) and also by the low site fidelity that this species shows (Nuñez et al. 2018).

\subsection{Sediment characterization and MPB abundance/diversity/composition in natural bioturbated and non-bioturbated patches}

Directed field sampling was conducted in summer 2014 in order to characterize sediment properties and MPB abundance/diversity/composition in naturally occurring bioturbated and non-bioturbated patches in Mar Chiquita mudflats. Along these mudflats are highly bioturbated patches that are interspersed with few or no bioturbated patches, and this feature has allowed assessing a broad range of ecological patterns (Botto \& Iribarne 1999, Escapa et al. 2004, Iribarne et al. 2005, Fanjul et al. 2007). To include environmental variability, we distributed our sampling effort in 3 different mudflat areas within the coastal lagoon, each area consisting of 2 paired patch types: high bioturbation intensity patches (crab sites) and nearby patches with low or no bioturbation (no-crab sites). In these patches, we characterized sediment physical properties (grain size distribution, water content and salinity) and MPB abundance/diversity/ composition and biomass.

In each patch (crab and no-crab sites), we randomly collected sediment samples during low tides, using corers of different diameter. A first set of samples $(2 \mathrm{~cm}$ diameter and $1 \mathrm{~cm}$ depth; $\mathrm{n}=10$ at each site) was used for determination of sediment physical parameters. Water content was obtained as the difference between wet and dry weight (after drying at $60^{\circ} \mathrm{C}$ to a constant weight). Sediment salt content was measured in a 1:2 dry-sediment/distilled water extract. Sediment salinity was then estimated from salt sediment content and water sediment content data. Grain size distribution was measured by wet sieving, using standard mesh size sieves $(500,250$, $125,62 \mu \mathrm{m})$. Each retained fraction, as well as the $<62 \mu \mathrm{m}$ fraction, was dried $\left(60^{\circ} \mathrm{C}\right.$ to constant weight) and weighed.

To estimate MPB biomass, a second set of sediment samples was collected $(2.4 \mathrm{~cm}$ diameter and $1 \mathrm{~cm}$ depth, sample size based on previous studies by Pan et al. 2013 and Alvarez et al. 2013 conducted in this region) and maintained in darkness and frozen until analysis. Biomass was estimated as total chlorophyll a ( $\mathrm{chl} \mathrm{a}$ ) content (Brotas et al. 1995). Pigments were extracted from sediment using 90\% acetone (Lorenzen 1967). Chl a and phaeophytin content were determined using spectrophotometric analysis (Jeffrey \& Humphrey 1975) before and after sample acidification.

A last set of sediment samples $(1 \mathrm{~cm}$ diameter and $1 \mathrm{~cm}$ depth; $\mathrm{n}=10$ at each site) was used for MPB parameters (species richness, evenness, total abundance, diversity). Samples were collected and immediately preserved in a mixture of distilled water, alcohol and formalin solution (6:3:1; Prescott 1951). To characterize MPB composition, the abundance of different groups included in MPB (cyanobacteria, chlorophytes, euglenophytes and diatoms) was quantified. MPB was identified to the lowest possible taxonomic level, following commonly used keys (i.e. cyanobacteria, Guarrera et al. 1972, Komárek \& Anagnostidis 1985, 1989, 1999, 2005; chlorophytes, Hindák 1990; euglenophytes, Tell \& Conforti 1986; and diatoms, Cox 1996, Prygiel \& Coste 2000). MPB counts were performed in a $0.5 \mathrm{ml}$ Sedgwick-Rafter chamber under an optical microscope (McAlice 1971). Species abundances were expressed as the number of individuals $\mathrm{cm}^{-2}$ of sediment, considering only those with chloroplast remains.

\subsection{Effects of regenerative bioturbation by $\mathbf{N}$. granulata on MPB}

In order to evaluate the effect of $N$. granulata bioturbation activity on MPB, a field experiment was conducted. The experimental site was near sampled area 2 in a patch with low/no bioturbation. It consisted of 2 experimental treatments ( $\mathrm{n}=10$ each): (1) 'crab exclusion' and (2) 'crab inclusion.' The experimental plots of each treatment (randomly assigned) were surrounded with plastic mesh (1 cm mesh size) boxes (all sides $0.6 \mathrm{~m}$ long, $0.5 \mathrm{~m}$ tall). Crab exclusions were achieved with a mesh box closed with a mesh lid, and additional smaller mesh wall $(0.1 \mathrm{~m}$ tall and $0.1 \mathrm{~cm}$ mesh size) attached to the bottom to prevent the entry of small crabs. Crab inclusions consisted of mesh boxes (similar those used for crab exclusion) with a half lid (to allow free access of crabs and to replicate the possible shading effect present in crab exclusions), and with smaller mesh added in 2 of the walls (to replicate the possible artifact effect on water flow dynamics). Crab density in crab-inclusion plots was maintained throughout the experiment, simulat- 
ing the natural densities in the study area ( 60 crabs $\mathrm{m}^{-2}$, Iribarne et al. 1997, Escapa et al. 2004).

Several previous studies have shown success of crab-inclusion experiments based on low or no mortality and the normal crab behavior evidenced by bioturbation rates similar to those at natural crab sites (e.g. Fanjul et al. 2007, 2008, 2011, Alberti et al. 2011). This kind of box design does not significantly affect flow dynamics or light incidence (Hillebrand \& Kahlert 2002, Armitage \& Fong 2006, Cheverie et al. 2014) and thus these boxes do not affect MPB dynamics (Alvarez et al. 2013). Once installed, the experiment ran for $60 \mathrm{~d}$ (summer 2015), and the experimental plots were periodically inspected to guarantee the absence of crabs in crab exclusions; small crabs were manually removed when necessary. Crab-inclusion plots were monitored to ensure that crabs were actively constructing and maintaining their burrows.

After $60 \mathrm{~d}$, sediment samples were collected from each plot. A set of samples $(2 \mathrm{~cm}$ diameter and $1 \mathrm{~cm}$ depth) was used for determination of physico-chemical parameters (water content, salinity, organic matter content). Water content and salinity were measured as detailed in Section 2.2. Organic matter (OM) content was determined by weight loss upon ignition $(5 \mathrm{~h}$ at $550^{\circ} \mathrm{C}$ ). $\mathrm{pH}$ was measured in situ in the top centimeter of sediment using a hand-held $\mathrm{pH}$ meter (FC200, Hanna Instruments). Oxygen profiles were assessed in situ by measuring oxygen concentration every $100 \mu \mathrm{m}$ in the top millimeter; and every $500 \mu \mathrm{m}$ between the first and third millimeter of depth. We constructed a device that consisted of a micromanipulator (MM2, Unisense AS) screwed to an iron stick. In each experimental plot, we first inserted the device into the sediment and then mounted the oxygen microsensor (Clark type glass microsensor; $50 \mu \mathrm{m}$ tip, fast response; Unisense) to the micromanipulator. Sensor current was measured with a picoammeter (PA2000; Unisense AS) that was placed outside the experimental boxes. The microelectrode was calibrated with both air-saturated and oxygen-free $\mathrm{N}_{2}$-saturated water at the same temperature and salinity as pore water. To avoid pseudoreplication, we measured oxygen concentration within each box at one randomly selected point, avoiding crab burrows, mounds and other biogenic structures. Grain size distribution was not measured in this experiment because over short time periods crab bioturbation does not affect mean particle size (e.g. Needham et al. 2011).

Another set of samples $(2.4 \mathrm{~cm}$ diameter and $1 \mathrm{~cm}$ depth) was collected for determination of chl a (details in Section 2.2). The last set of sediment samples $(1 \mathrm{~cm}$ diameter and $1 \mathrm{~cm}$ depth) was collected for determi- nation of MPB parameters. Composition was determined as detailed in Section 2.2. Richness, abundance, diversity and evenness were calculated using these data. Gross primary production (GPP) was estimated by the light-dark shift method inside experimental plots using the oxygen microsensors described above, following Revsbech \& Jorgensen (1983). Measurements were taken every $100 \mu \mathrm{m}$ until readings stabilized, up to depths where values were equal to 0. Dark periods were generated abruptly, covering the whole equipment with an opaque cover; meanwhile, the data were being transmitted to a computer in real time through an A/D C216 USB converter (SensorTrace suite version 1.0; Unisense). GPP was then estimated by integrating data obtained at each depth following Glud et al. (1992). Values obtained in $\mathrm{mmol} \mathrm{O}_{2}$ $\mathrm{d}^{-1} \mathrm{~m}^{-2}$ were then converted to $\mathrm{g} \mathrm{C} \mathrm{d}^{-1} \mathrm{~m}^{-2}$ using the photosynthetic quotient (Strickland \& Parsons 1972).

\subsection{Data analysis}

Differences in physico-chemical parameters (i.e. sediment salinity, water content, $\mathrm{pH}, \mathrm{OM}), \mathrm{MPB}$ characteristics (i.e. chl $a$, richness, Shannon index and evenness) between crab and no-crab sites for the field sampling data, and also differences in GPP between crab-inclusion and crab-exclusion treatments for the field experiment data, were tested using $t$-tests (Zar 1999). Parametric tests were performed after confirming normality and homoscedasticity; otherwise, we used a Wilcoxon test (Conover 1999). Differences in the proportion of grain size fractions were analyzed with permutational ANOVA (PERMANOVA) based on the Euclidean dissimilarity index (Anderson 2001). Differences in MPB composition between crab and no-crab sites and between crab-inclusion and -exclusion treatments were tested using PERMANOVA, based on the BrayCurtis dissimilarity index with 9999 permutations (Anderson 2001). PERMANOVA was used to compare sediment oxygen profiles between treatments based on the Euclidean dissimilarity index (Anderson 2001).

\section{RESULTS}

\subsection{Sediment characterization and MPB abundance/diversity/composition in natural bioturbated and non-bioturbated patches}

Sediment salinity was higher at crab sites, with an average value of 18 (Table 1). Sediment water content did not differ among sites, presenting an 
Table 1. Summary of statistical tests performed to compare mean (SD) values of measured variables at crab and no-crab sites. $T_{\text {obs }}$ : observed $t$-statistic value; ${ }^{*}$ significant at $\mathrm{p}<0.05$

\begin{tabular}{|c|c|c|c|c|c|c|}
\hline Variable & Crab sites & No-crab sites & $\mathrm{df}$ & $T_{\text {obs }}$ & $\mathrm{p}$ & Test \\
\hline $\begin{array}{l}\text { Water content }{ }^{\mathrm{a}} \\
(\%)\end{array}$ & $37.76(8.07)$ & $38.90(6.85)$ & 58 & -0.79 & 0.43 & $t$-test \\
\hline Salinity & $18.01(7.16)$ & 7.03 (3.49) & 58 & 856 & $<0.0001^{*}$ & $\begin{array}{l}\text { Wilcoxon } \\
\text { test }\end{array}$ \\
\hline $\begin{array}{l}\text { Chlorophyll a } \\
\left(\mu \mathrm{cm}^{-2}\right)\end{array}$ & $3.47(0.83)$ & $4.5(0.84)$ & 58 & -4.76 & $<0.0001^{*}$ & $t$-test \\
\hline
\end{tabular}

average of $38 \%$ (Table 1). Grain size distribution was different among crab and no-crab sites in areas 1 and $3\left(F_{5,24}=30.08 ; \mathrm{p}=0.01\right.$ and 0.02 , respectively), but there were no differences in area $2(\mathrm{p}=$ $0.18)$. No-crab sites had higher proportions of fine sand $(125 \mu \mathrm{m})$ than crab sites, and both had a lower proportion of medium and coarse sands than of fine sand (Table 2).

In terms of MPB, biomass (estimated as chl a content) presented the highest values at no-crab sites (Table 1). MPB was composed of a total of 36 taxa (i.e. each identified species, genus or group listed in Table 3). At crab sites, a total of 14, 15 and 20 taxa were identified in areas 1, 2 and 3, respectively, and 19 taxa were identified at no-crab sites (in each of 3 areas; Table 3). These taxa belonged to 4 MPB groups (i.e. diatoms, cyanobacteria, euglenophytes and chlorophytes). At crab sites, we found the highest abundance, where the mean value reached up to $3.20 \times 10^{6}$ ind $\mathrm{cm}^{-2}$ (SD: $1.02 \times 10^{6} ;$ Fig. $1 \mathrm{~A}$; observed $t$-statistic value $\left.\left[T_{\text {obs }}\right]=3.14 ; \mathrm{p}<0.05\right)$. Richness and Shannon index were higher at no-crab sites (Fig. 1B; Wilcoxon test: $T=193.5 ; \mathrm{p}<0.05 \&$ Fig. $1 \mathrm{D}$; $T_{\text {obs }}=-2.65 ; \mathrm{p}<0.05$ ), with no differences in evenness between sites (Fig. $1 C_{i} T_{\text {obs }}=0.06 ; p>$ $0.05)$. Diatoms and cyanobacteria were the most abundant groups, while euglenophytes and chlorophytes presented lower abundances (Table 3). Epipelic diatoms (motile taxa) represented $75 \%$ of diatom richness. Diatoms did not change in relative abundance between crab and no-crab sites, representing approximately $50 \%$ of the total abundance (Fig. 2B). Relative abundance of cyanobacteria was $10 \%$ higher at crab sites, and chlorophytes were more abundant at no-crab sites (Fig. 2B). These differences in relative abundance of different taxa between sites supported the PERMANOVA results, which indicated that MPB composition differed between sites (Fig. 2A; $\left.F_{1,58}=28.32 ; \mathrm{p}<0.05\right)$.

\subsection{Effects of regenerative bioturbation by Neohelice granulata on MPB}

Sediment salinity was similar between treatments (Table 4). Water content was higher and $\mathrm{pH}$ was lower in crab-exclusion plots (Table 4). OM content did not differ between treatments, presenting a mean value of $4.6 \%$ (Table 4 ). Oxygen profiles were different between treatments (Fig. $3 ; F_{1,12}=6.29 ; \mathrm{p}<0.05$ ): up to the top millimeter, oxygen concentration was higher in crab-inclusion plots. The highest oxygen concentration was found at $0.2 \mathrm{~mm}$ depth in crabinclusion plots and gradually descended to $\sim 0 \mu \mathrm{M}$ at $1 \mathrm{~mm}$ depth. In crab-exclusion plots, the highest value was registered at $0.1 \mathrm{~mm}$, and oxygen concentration descended steeply from a depth of $0.3 \mathrm{~mm}$ to $0 \mu \mathrm{M}$ at $1 \mathrm{~mm}$ depth.

Table 2. Sediment fraction characterization at crab sites and no-crab sites with total averages. Values correspond to the median (SD) fraction proportion

\begin{tabular}{|lcccccccc}
\hline $\begin{array}{l}\text { Sediment } \\
\text { fraction }(\%)\end{array}$ & $\begin{array}{c}\text { Crab site } \\
1\end{array}$ & $\begin{array}{c}\text { Crab site } \\
2\end{array}$ & $\begin{array}{c}\text { Crab site } \\
3\end{array}$ & $\begin{array}{c}\text { Average } \\
\text { crab sites }\end{array}$ & $\begin{array}{c}\text { No-crab } \\
\text { site 1 }\end{array}$ & $\begin{array}{c}\text { No-crab } \\
\text { site 2 }\end{array}$ & $\begin{array}{c}\text { No-crab } \\
\text { site 3 }\end{array}$ & $\begin{array}{c}\text { Average } \\
\text { No-crab sites }\end{array}$ \\
\hline $\begin{array}{l}\text { Mud } \\
(<62 \mu)\end{array}$ & $20.37(3.02)$ & $19.27(1.82)$ & $35.24(4.11)$ & $24.96(8.54)$ & $15.66(1.67)$ & $16.47(2.65)$ & $18.01(1.78)$ & $16.71(2.38)$ \\
$\begin{array}{l}\text { Very fine sand } \\
(62-125 \mu)\end{array}$ & $13.62(2.69)$ & $25.28(3.29)$ & $43.32(3.55)$ & $27.41(11.98)$ & $20.23(7.21)$ & $16.90(4.80)$ & $25.21(4.41)$ & $20.78(6.17)$ \\
$\begin{array}{l}\text { Fine sand } \\
(125-250 \mu)\end{array}$ & $32.34(3.08)$ & $29.48(2.05)$ & $15.49(5.07)$ & $25.77(7.73)$ & $58.84(8.00)$ & $41.45(8.77)$ & $38.33(4.49)$ & $46.21(10.68)$ \\
$\begin{array}{l}\text { Medium sand } \\
(250-500 \mu)\end{array}$ & $17.25(7.19)$ & $13.31(3.84)$ & $2.72(0.92)$ & $11.09(8.87)$ & $1.21(0.33)$ & $8.63(4.44)$ & $7.53(0.31)$ & $5.79(4.21)$ \\
$\begin{array}{l}\text { Coarse sand } \\
(>500 \mu)\end{array}$ & $12.78(1.52)$ & $12.19(2.94)$ & $2.36(1.58)$ & $9.11(5.22)$ & $4.88(1.02)$ & $10.28(2.31)$ & $6.86(2.68)$ & $7.34(3.49)$ \\
& & & & & & & & \\
\hline
\end{tabular}


Table 3. Abundance of microphytobenthic taxa found at sites with and without crabs. Values correspond to mean (SD) ind. $\times 10^{4} \mathrm{~cm}^{-2}$ of sediment. Dashes indicate taxa not found at the corresponding site

\begin{tabular}{|c|c|c|c|c|c|c|}
\hline \multirow{2}{*}{ Identified taxa } & \multicolumn{3}{|c|}{ - Crab sites } & \multicolumn{3}{|c|}{ - No-crab sites } \\
\hline & 1 & 2 & 3 & 1 & 2 & 3 \\
\hline \multicolumn{7}{|l|}{ Cyanobacteria } \\
\hline Chroococcus sp. & $2.49(2.23)$ & $1.64(0.71)$ & $2.4(2.02)$ & $2.15(1.48)$ & $1.36(1.7)$ & $0.84(0.54)$ \\
\hline Chroococcal spp. & $9.03(5.29)$ & $4.88(1.87)$ & $0.81(0.82)$ & $2.98(2.5)$ & $3.33(3.07)$ & $1(0.75)$ \\
\hline Spirulina sp. & $1.37(0.85)$ & $0.42(0.353)$ & $4.87(3.69)$ & $4.3(1.41)$ & $1(0.53)$ & $2.69(1.85)$ \\
\hline Filamentous cyanobacteria ${ }^{\mathrm{a}}$ & $152(81)$ & $148(49.51)$ & $52.20(26)$ & $108(34.40)$ & $53.30(16.50)$ & $23.30(5.62)$ \\
\hline \multicolumn{7}{|l|}{ Chlorophyta } \\
\hline Schroederia nitzschioides & - & - & $10.30(8.32)$ & $2.22(0.78)$ & $0.85(1.01)$ & $21.6(11.30)$ \\
\hline S. setigera & - & - & $3.63(3.27)$ & $13.30(6.27)$ & $2.12(1.46)$ & $3.36(1.38)$ \\
\hline Ulothrix sp. & - & - & $0.03(0.06)$ & $0.72(0.72)$ & $0.25(0.24)$ & $0.07(0.08)$ \\
\hline Unidentified Clorophyte & $1.69(1.43)$ & $3.19(1.32)$ & $0.58(1.51)$ & $0.09(0.09)$ & $0.70(0.69)$ & - \\
\hline \multicolumn{7}{|l|}{ Euglenophyta } \\
\hline Euglena sp. & $0.81(0.41)$ & $3.90(2.55)$ & $2.31(1.40)$ & $2.55(0.49)$ & $0.95(0.32)$ & $0.51(0.36)$ \\
\hline \multicolumn{7}{|l|}{ Bacillariophyta } \\
\hline Asterionellopsis sp. & $0.08(0.11)$ & $0.03(0.09)$ & $0.60(0.46)$ & $0.02(0.04)$ & - & $1.36(0.86)$ \\
\hline Entomoneis alata & $6.01(2.45)$ & $5.15(2.16)$ & $6.50(3.40)$ & $5.76(1.2)$ & $7.37(7.28)$ & $4.39(2.3)$ \\
\hline Melosira moniliformis & $1.68(1.12)$ & $0.32(0.39)$ & $1.57(0.97)$ & $0.40(0.39)$ & $0.13(0.18)$ & $1.03(0.85)$ \\
\hline Nitzschia filiformis & - & $0.27(0.22)$ & $0.06(0.08)$ & $0.26(0.83)$ & $0.05(0.10)$ & - \\
\hline N. longissima var. closterium & $0.24(0.25)$ & $0.08(0.08)$ & $0.28(0.16)$ & $0.11(0.09)$ & $0.12(0.20)$ & $1.57(0.96)$ \\
\hline Nitzschia sp 1. & - & - & $0.15(0.49)$ & - & $0.19(0.38)$ & $0.02(0.05)$ \\
\hline Nitzschia sp 2. & - & - & - & - & - & $0.59(0.42)$ \\
\hline Odontella aurita & $0.28(0.18)$ & $0.27(0.27)$ & $1.58(0.52)$ & $0.65(0.81)$ & $0.10(0.10)$ & $0.56(0.34)$ \\
\hline Surirella spp. & $13.20(5.84)$ & $14.20(3.94)$ & $10(3.48)$ & $17.70(5.84)$ & $10.70(6.82)$ & $3.80(1.79)$ \\
\hline Trybionella compressa & - & - & $2.35(1.31)$ & $3.79(1.42)$ & $2.34(1.02)$ & $1.76(1)$ \\
\hline Other pennate diatoms ${ }^{\mathrm{b}}$ & $171(34.60)$ & $178(36.9)$ & $133(31.70)$ & $154(34.40)$ & $150(31.80)$ & $105(40.30)$ \\
\hline Other centric diatoms ${ }^{\mathrm{c}}$ & $1.33(0.71)$ & $0.87(0.56)$ & $3.95(0.66)$ & $1.54(0.31)$ & $0.46(0.21)$ & $3.31(1.50)$ \\
\hline
\end{tabular}


Fig. 1. Total microphytobenthos (A) abundance, (B) richness, (C) evenness and (D) Shannon diversity index at crab sites and no-crab sites. Here, and in other figures, the box represents $25^{\text {th }}$ and $75^{\text {th }}$ quartiles, the median is the line within the box, and bars are the maximum and minimum values. ${ }^{*} \mathrm{p}<0.05$
MPB biomass (estimated as chl a content) did not differ between treatments (Fig. 4A; $T_{\text {obs }}=-1.17 ; \mathrm{p}>0.05$ ), and 14 taxa were identified in the experimental plots. Total abundance was higher in crab-exclusion plots (Fig. 4B; $T_{\text {obs }}=-4.53 ; \mathrm{p}<0.05$ ), and no differences were found for diversity parameters between treatments (richness: Fig. 4C; Wilcoxon test: $T=51.5$; $\mathrm{p}>0.05$; evenness: Fig. 4D; $T_{\text {obs }}=$ $-0.55 ; \mathrm{p}>0.05$ and Shannon index: Fig. $\left.4 \mathrm{E} ; T_{\text {obs }}=-0.6 ; \mathrm{p}>0.05\right)$. Diatoms, composed of $85 \%$ epipelic taxa, presented the highest abundance, followed by cyanobacteria, chlorophytes and euglenophytes (Table 5). Analysis of composition using PERMANOVA showed that communities were different between treatments (Fig. $5_{i} F_{1,18}=$ 6.26; p < 0.05), possibly related to lower diatom relative abundance and 

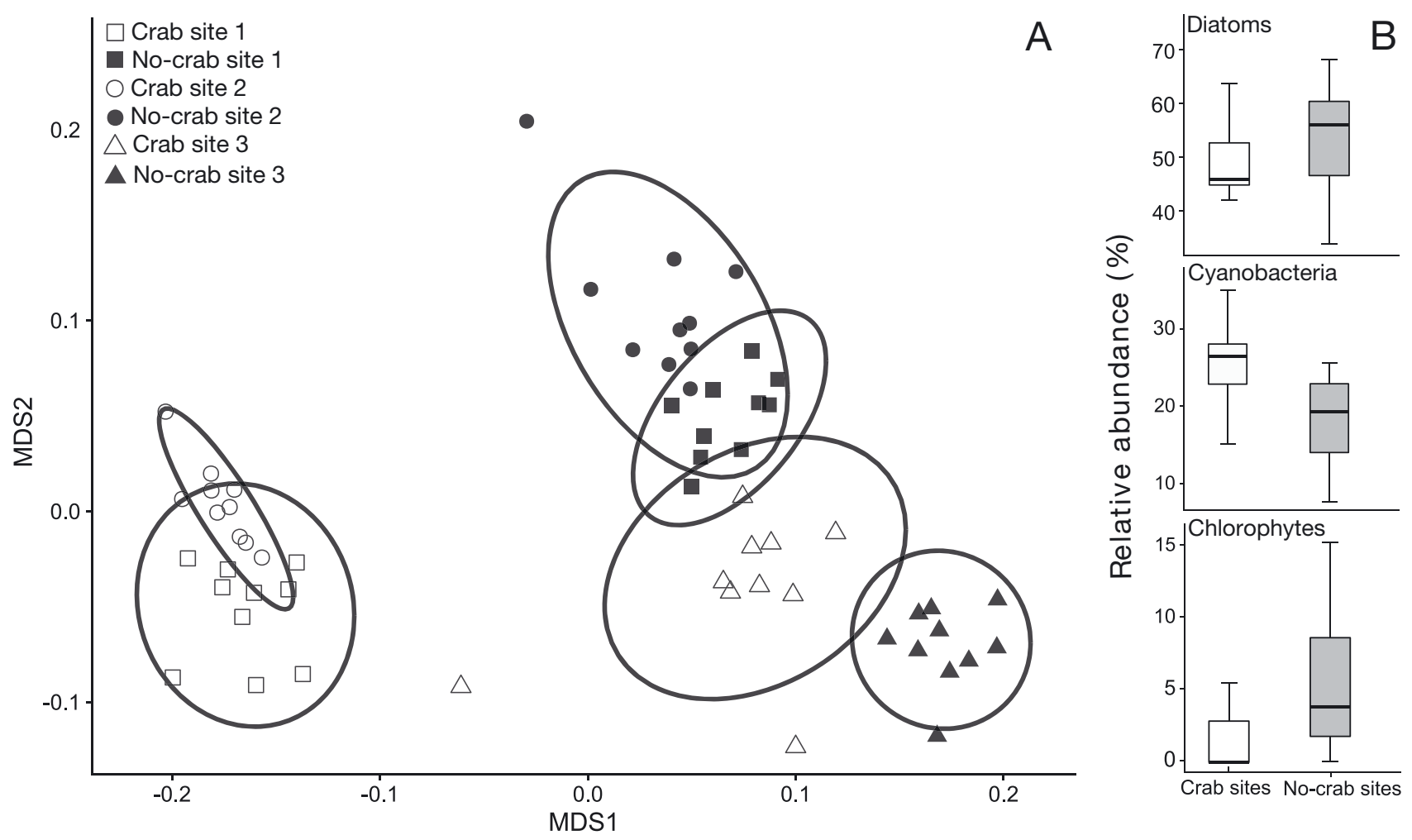

Fig. 2. (A) Multi-dimensional scaling plot based on total abundance for each identified microphytobenthic (MPB) taxon at crab sites $(n=3)$ and no-crab sites $(n=3)$. Lines represent the confidence ellipse at the 0.95 level. Stress: 0.09. (B) Relative abundance of main MPB groups at crab and no-crab sites

higher cyanobacteria relative abundance in crabexclusion treatments (Fig. 5B). GPP was higher in crab-inclusion plots (Fig. $4 \mathrm{~F}_{;} T_{\text {obs }}=-2.39 ; \mathrm{p}<0.05$ ), with a mean value of $657.29 \mathrm{mmol} \mathrm{O}_{2} \mathrm{~d}^{-1} \mathrm{~m}^{-2}$, approximately double the production observed in crabexclusion plots.

\section{DISCUSSION}

\subsection{Regenerative bioturbation effects on MPB}

In our study site, MPB were dominated by diatoms $(63 \%)$ and cyanobacteria $(30 \%)$, and also contained euglenophytes and chlorophytes $(7 \%)$.

Diatoms showed the highest richness (20 taxa), while the other groups were less well represented (cyanobacteria $=$ 8 ; euglenophytes $=1$; chlorohytes $=4$ taxa). Grain size distribution is a key factor for classification of benthic environments, and our data from the 3 areas showed different grain size distribution between crab and no-crab sites in 2 of these areas. The differ- ences in grain size between crab and no-crab sites could be related to the changes in MPB composition that we found between sites. It has been proposed that cyanobacteria prefer sandy sediments for colonization (Paterson \& Hagerthey 2001). Our results showed that the relative abundance of cyanobacteria was almost $10 \%$ higher at crab sites, where the proportion of medium and coarse sands (250-500 and $>500 \mu \mathrm{m})$ is higher than at no-crab sites, which matches with what was expected. Benthic diatoms have been conventionally divided into 2 groups with regard to their structure: epipelon, the free-living diatoms that usually dominate mud and very fine sand environments; and epipsammon, the diatoms

Table 4. Summary of statistical tests performed to compare mean values of measured variables in crab-inclusion and crab-exclusion treatments. Values correspond to means (SD). $T_{\text {obs: }}$ observed $t$-statistic value; OM: organic matter; ${ }^{*}$ significant at $\mathrm{p}<0.05$

\begin{tabular}{|lrccccc|}
\hline Variable & Inclusion & Exclusion & df & $T_{\text {obs }}$ & $\mathrm{p}$ & Test \\
\hline Salinity & $12.60(3.72)$ & $9.20(4.83)$ & 18 & -1.76 & 0.09 & $t$-test \\
Water content (\%) & $40(9.71)$ & $52.90(13.44)$ & 18 & 2.46 & $0.02^{*}$ & $t$-test \\
OM (\%) & $4.30(1.07)$ & $4.84(0.91)$ & 18 & 1.20 & 0.24 & $t$-test \\
pH & $7.16(0.19)$ & $6.60(0.17)$ & 18 & 1 & $<0.01^{*}$ & $\begin{array}{l}\text { Wilcoxon } \\
\text { test }\end{array}$ \\
\hline
\end{tabular}




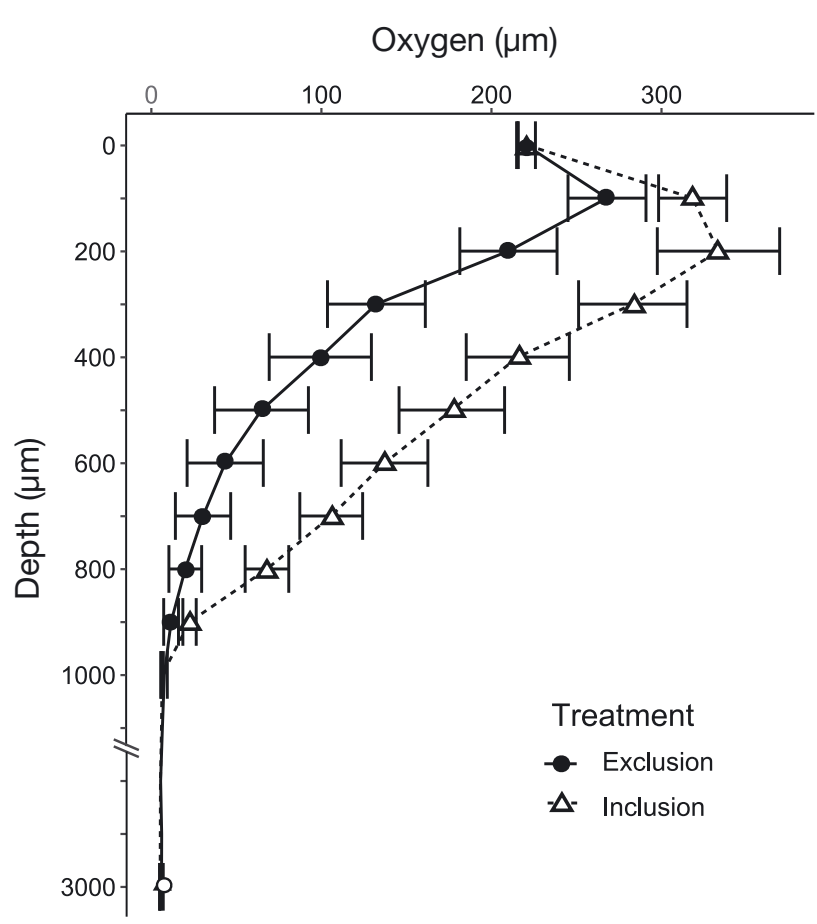

Fig. 3. Oxygen concentration profile in crab-exclusion and crab-inclusion treatments from the field experiment. Values are means $\pm \mathrm{SE}$ attached to sand grains that are commonly found in sandflats (>500 $\mu \mathrm{m})$ (e.g. Round 1965, Admiraal 1984). There were no differences when comparing the relative abundance of diatoms between crab and no-crab sites; however, if epipelic-epipsammic classification is considered, we found that some of the epipelic taxa presented almost the double relative abundance in no-crab than in crab sites, where the proportion of fine sands is higher than in crab sites.

Exhaustive analysis of MPB composition showed that the dissimilarity between crab and no-crab sites was greater in 2 of the 3 areas that we sampled. There is an increasing consensus that the effects of different kinds of bioturbation (like other ecological processes) depend on the environmental and biological context (Needham et al. 2011). The same type of bioturbation at the same intensity may produce different effects on biogeochemical processes depending on sedimentary context (e.g. cohesive vs. noncohesive sediments; Mermillod-Blondin \& Rosenberg 2006). Particularly, the effect of crab bioturbation on ecosystem processes is highly context dependent (Fanjul et al. 2011, Needham et al. 2011).

When we manipulated regenerative bioturbation intensity in experimental plots, we found that crabs
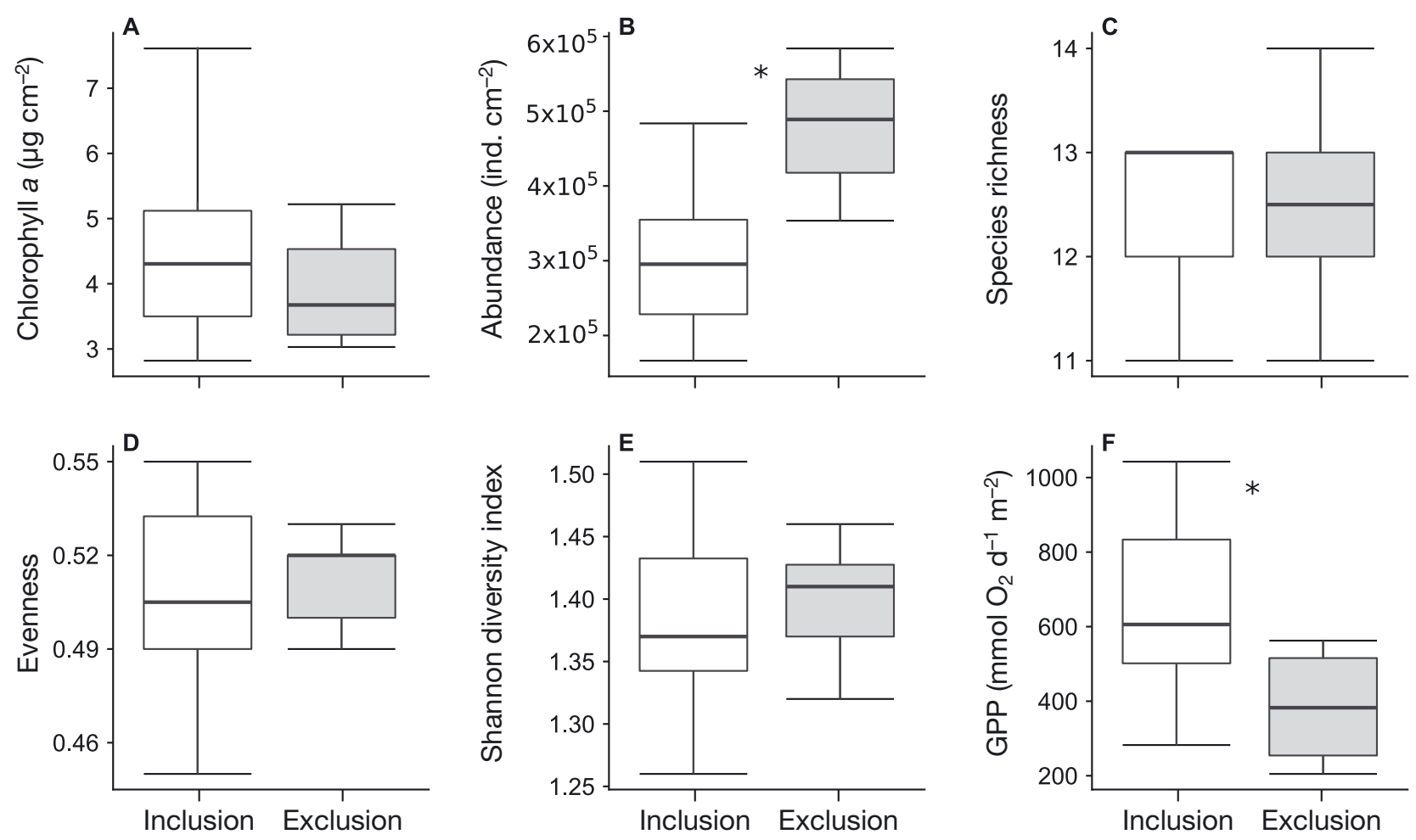

Fig. 4. (A) Biomass (measured as chlorophyll a concentration), (B) abundance, (C) richness, (D) evenness, (E) Shannon diversity index and (F) gross primary production (GPP) of microphytobenthos in crab-exclusion and crab-inclusion treatments from the field experiment. ${ }^{*} \mathrm{p}<0.05$ 
this study are the first for this region; however, these are micro-scale estimates and should be interpreted with caution since they do not include processes that operate on a larger scale (e.g. macrofaunal community respiration or large-scale environmental heterogeneity). Our results show high MPB productivity, presenting values near the highest registered for similar systems (median $0.5 \mathrm{~g} \mathrm{C} \mathrm{m}^{-2} \mathrm{~d}^{-1}$; Cebrian 1999). MPB primary production rates are as high as those for the dominant intertidal vascular plants of this region. Primary production of Sporobolus densiflorus in our study region is on average $2.46 \mathrm{~g} \mathrm{C}$ $\mathrm{m}^{-2} \mathrm{~d}^{-1}$ (González Trilla et al. 2010), which is similar to the value that we registered for MPB without crabs $\left(2.38 \mathrm{~g} \mathrm{C} \mathrm{m}^{-2} \mathrm{~d}^{-1}\right)$ and half of the value registered with crabs $\left(4.07 \mathrm{~g} \mathrm{C} \mathrm{m}^{-2} \mathrm{~d}^{-1}\right)$. Since almost half of total areal extension corresponding to mudflats at our study site is highly bioturbated by crabs (Iribarne et al. 2005), MPB makes a significant contribution to primary production in this particular zone (i.e. softbottom tidal flats). In addition, the presence of MPB in marsh and shallow sub-tidal sediments could also significantly contribute to global productivity (Hughes 1999). In this sense, MPB contribution to global primary production in our study site is underestimated because we did not take into account the high MPB abundance in salt marshes (M. Giorgini unpubl. data).

The importance of bioturbation effects in the functioning of intertidal systems (Teal et al. 2013) and on MPB productivity (Lohrer et al. 2004) is widely recognized, but there is scarce evidence regarding the role of regenerative bioturbation on MPB productivity (but see Needham et a. 2011). Here, we have demonstrated that the burrowing crab $N$. granulata enhances MPB primary production to levels almost twice as high as those in areas without bioturbation, while at the same time reducing MPB total abundance, thus evidencing an increase of biomass-specific productivity rates. Chl a concentration is often used as a proxy of MPB biomass. In this sense, we expected a positive correlation between $\mathrm{chl} a$ and abundance and also between chl $a$ and MPB primary production. In our experiment, we found the same concentration of chl a between crab-exclusion and crab-inclusion treatments. In contrast, we found higher MPB abundance but lower MPB primary production in crab-exclusion plots. This may be due to the changes observed in MPB composition between treatments, which could imply shifts for taxa with different pigment production, resulting in a non-linear relationship between productivity and pigment concentration (Falkowski \& Kiefer 1985). These results of primary production enhancement by bioturbation and uncorrelated chl $a$ and productivity are similar to results reported for the regenerative bioturbator $\mathrm{crab}$ Austrohelice crassa (Needham et al. 2011), and surficial biodiffuser urchins of the genus Echinocardium (Lohrer et al. 2004), which enhance MPB production up to $35 \%$.

The enhancement of primary production could be explained by several factors. First, regenerative bioturbation reduces MPB abundance, which could benefit productivity by alleviating competition (Morrisey 1988). Particularly, the reduction in total abundance of microalgae in our system could be attributed to the decline in the abundance of cyanobacteria, a group characterized by a great functional diversity but a low photosynthetic rate (e.g. Glud et al. 1992). Second, in our experiment, oxygen concentration was higher in bioturbated than in non-bioturbated sediment, so this kind of reworking is likely to increase the supply of resources and oxic layers, probably stimulating aerobic microbial metabolism (e.g. Fanjul et al. 2015). The increase in sediment oxygen concentration is usually related to changes in grain size distribution, but over a short period, grain size is not affected by regenerative bioturbation (Needham et al. 2011). Thus, changes in sediment oxygen concentration may be due to an indirect effect of the higher GPP generated by regenerative bioturbation or by a direct effect of bioturbation. Since we did not test these hypotheses, we could not attribute the increase in oxygen concentration to either of these factors. Finally, it is known that regenerative bioturbation can improve ammonia availability in the surface sediment layers (e.g. Fanjul et al. 2011, Needham et al. 2011) where MPB live, and as a consequence MPB primary productivity increases (Lohrer et al. 2004, Sandwell et al. 2009). Thus, throughout the enhancement of benthic metabolism and ammonia availability, regenerative bioturbators could be stimulating MPB primary production. At bioturbated sediments, we found lower water content, which is commonly expected to cause negative effects on MPB primary production (Coelho et al. 2009). However, the combined increase in oxygen concentration and ammonia availability could result in increased MPB productivity (Needham et al. 2011), prevailing over the possible negative effects of low water content. MPB may also be negatively affected by other kinds of bioturbation (e.g. epifaunal biodiffusers; Webb \& Eyre 2004) due to different effects on physico-chemical sedimentary environment and also because bioturbators often graze on MPB. Surficial biodiffusers, for example, can mix the surficial sediment as they move, and they have little if any effect upon the increase in 
ammonia release (e.g. sea cucumber Australostichopus mollis, sand dollars), and the net result is a negative effect on primary producer biomass (MacTavish et al. 2012, Li et al. 2013). Contrary to these kinds of bioturbation, net effects of regenerative bioturbation by $N$. granulata are positive for MPB productivity, so based on our results we suggest that this crab constitutes an important biological force that enhances primary production at SWA mudflats.

\subsection{Conclusions}

Our results show that the burrowing crab N. granulata affects the abundance, composition and the main ecosystem functions mediated by MPB at the SWA mudflats. The decrease in MPB abundance could be explained by a reduction in cyanobacterial abundance and, as a consequence, MPB composition is affected. The modification of MPB composition together with the increased availability of ammonia could explain the increase in MPB primary production. $N$. granulata enhances the productivity of marsh plants (Sporobolus spp.; Daleo et al. 2007), and similarly, regenerative bioturbation by $N$. granulata increases MPB primary production. To our knowledge, this is the first study where the primary production of MPB was quantified in this region. The production rate is high when compared with similar systems and almost equal to the production of marsh plants that occur in the upper intertidal levels.

Acknowledgements. We thank Juan Alberti for his help with statistical analysis. We also thank the Editor and three anonymous reviewers for greatly improving earlier versions of this manuscript. This project was supported by grants from ANPCYT (PICT 3823 to O.I. and E.F. and PICT 2565 to M.E.), CONICET (to O.I.) and UNMdP (PIP 424 to O.I.). M.G., A.M. and C.D. were supported by scholarships from CONICET (Argentina).

\section{LITERATURE CITED}

Admiraal W (1984) The ecology of estuarine sedimentinhabiting diatoms. Prog Phycol Res 3:269-322

Alberti J, Cebrian J, Casariego AM, Canepuccia A, Escapa M, Iribarne O (2011) Effects of nutrient enrichment and crab herbivory on a SW Atlantic salt marsh productivity. J Exp Mar Biol Ecol 405:99-104

Alberti J, Daleo P, Fanjul E, Escapa M, Botto F, Iribarne O (2015) Can a single species challenge paradigms of salt marsh functioning? Estuaries Coasts 38:1178-1188

Alberti J, Cebrian J, Alvarez F, Escapa M and others (2017) Nutrient and herbivore alterations cause uncoupled changes in producer diversity, biomass and ecosystem function, but not in overall multifunctionality. Sci Rep 7: $1-9$
Alvarez MF, Esquius KS, Addino M, Alberti J, Iribarne O, Botto F (2013) Cascading top-down effects on estuarine intertidal meiofaunal and algal assemblages. J Exp Mar Biol Ecol 440:216-224

Anderson MJ (2001) A new method for non-parametric multivariate analysis of variance. Austral Ecol 26:32-46

* Armitage AR, Fong P (2004) Upward cascading effects of nutrients: shifts in a benthic microalgal community and a negative herbivore response. Oecologia 139:560-567

Armitage AR, Fong P (2006) Predation and physical disturbance by crabs reduce the relative impacts of nutrients in a tidal mudflat. Mar Ecol Prog Ser 313:205-213

Armitage AR, Gonzalez VL, Fong P (2009) Decoupling of nutrient and grazer impacts on a benthic estuarine diatom assemblage. Estuar Coast Shelf Sci 84:375-382

Barth HJ (2003) The influence of cyanobacteria on oil polluted intertidal soils at the Saudi Arabian Gulf shores. Mar Pollut Bull 46:1245-1252

Bertics VJ, Ziebis W (2009) Biodiversity of benthic microbial communities in bioturbated coastal sediments is controlled by geochemical microniches. ISME J 3:1269-1285

Bertics VJ, Sohm JA, Treude T, Chow CET, Capone DG, Fuhrman JA, Ziebis W (2010) Burrowing deeper into benthic nitrogen cycling: the impact of bioturbation on nitrogen fixation coupled to sulfate reduction. Mar Ecol Prog Ser 409:1-15

*Biles CL, Paterson DM, Ford RB, Solan M, Raffaelli DG (2002) Bioturbation, ecosystem functioning and community structure. Hydrol Earth Syst Sci 6:999-1005

* Blackford JC (2002) The influence of microphytobenthos on the Northern Adriatic ecosystem: a modelling study. Estuar Coast Shelf Sci 55:109-123

* Bortolus A, Iribarne O (1999) Effects of the SW Atlantic burrowing crab Chasmagnathus granulata on a Spartina salt marsh. Mar Ecol Prog Ser 178:79-88

Bortolus A, Schwindt E, Iribarne O (2002) Positive plantanimal interactions in the high marsh of an Argentinean coastal Lagoon. Ecology 83:733-742

Botto F, Iribarne O (1999) Effect of the burrowing crab Chasmagnathus granulata (Dana) on the benthic community of a SW Atlantic coastal lagoon. J Exp Mar Biol Ecol 241: 263-284

Botto F, Iribarne O (2000) Contrasting effects of two burrowing crabs (Chasmagnathus granulata and UCa uruguayensis) on sediment composition and transport in estuarine environments. Estuar Coast Shelf Sci 51: 141-151

* Botto F, Valiela I, Iribarne O, Martinetto P, Alberti J (2005) Impact of burrowing crabs on $\mathrm{C}$ and $\mathrm{N}$ sources, control, and transformations in sediments and food webs of SW Atlantic estuaries. Mar Ecol Prog Ser 293:155-164

Botto F, Iribarne O, Gutierrez J, Bava J, Gagliardini A, Valiela I (2006) Ecological importance of passive deposition of organic matter into burrows of the SW Atlantic crab Chasmagnathus granulatus. Mar Ecol Prog Ser 312: 201-210

Brotas V, Cabrita T, Portugal A, Serôdio J, Catarino F (1995) Spatio-temporal distribution of the microphytobenthic biomass in intertidal flats of Tagus Estuary (Portugal). Hydrobiologia 300:93-104

Cebrian J (1999) Patterns in the fate of production in plant communities. Am Nat 154:449-468

* Cheverie AV, Hamilton DJ, Coffin MRS, Barbeau MA (2014) Effects of shorebird predation and snail abundance on an intertidal mudflat community. J Sea Res 92:102-114 
Coelho H, Vieira S, Serôdio J (2009) Effects of desiccation on the photosynthetic activity of intertidal microphytobenthos biofilms as studied by optical methods. J Exp Mar Biol Ecol 381:98-104

Conover WJ (1999) Practical nonparametric statistics, $3^{\text {rd }}$ edn. John Wiley \& Sons, New York, NY

Consalvey M, Paterson DM, Underwood GJ (2004) The ups and downs of life in a benthic biofilm: migration of benthic diatoms. Diatom Res 19:181-202

Cox EJ (1996) Identification of freshwater diatoms from live material. Chapman \& Hall, London

Daleo P, Iribarne O (2009) Beyond competition: the stressgradient hypothesis tested in plant-herbivore interactions. Ecology 90:2368-2374

* Daleo P, Fanjul E, Casariego AM, Silliman BR, Bertness MD, Iribarne O (2007) Ecosystem engineers activate mycorrhizal mutualism in salt marshes. Ecol Lett 10:902-908

de Brouwer JFC, Wolfstein K, Stal LJ (2002) Physical characterization and diel dynamics of different fractions of extracellular polysaccharides in an axenic culture of a benthic diatom. Eur J Phycol 37:37-44

* Duarte CM (1995) Submerged aquatic vegetation in relation to different nutrient regimes. Ophelia 41:87-112

*Emmerson MC, Solan M, Emes C, Paterson DM, Raffaelli D (2001) Consistent patterns and the idiosyncratic effects of biodiversity in marine ecosystems. Nature 411:73-77

* Escapa M, Iribarne O, Navarro D (2004) Effects of the intertidal burrowing crab Chasmagnathus granulatus on infaunal zonation patterns, tidal behavior, and risk of mortality. Estuaries 27:120-131

Escapa M, Minkoff DR, Perillo GME, Iribarne O (2007) Direct and indirect effects of burrowing crab Chasmagnathus granulatus activities on erosion of southwest Atlantic Sarcocornia-dominated marshes. Limnol Oceanogr 52:2340-2349

Escapa M, Perillo GME, Iribarne O (2008) Sediment dynamics modulated by burrowing crab activities in contrasting SW Atlantic intertidal habitats. Estuar Coast Shelf Sci 80: 365-373

Falkowski P, Kiefer DA (1985) Chlorophyll a fluorescence in phytoplankton: relationship to photosynthesis and biomass. J Plankton Res 7:715-731

Fanjul E, Grela MA, Iribarne O (2007) Effects of the dominant SW Atlantic intertidal burrowing crab Chasmagnathus granulatus on sediment chemistry and nutrient distribution. Mar Ecol Prog Ser 341:177-190

Fanjul E, Grela MA, Canepuccia A, Iribarne O (2008) The Southwest Atlantic intertidal burrowing crab Neohelice granulata modifies nutrient loads of phreatic waters entering coastal area. Estuar Coast Shelf Sci 79:300-306

Fanjul E, Bazterrica MC, Escapa M, Grela MA, Iribarne O (2011) Impact of crab bioturbation on benthic flux and nitrogen dynamics of Southwest Atlantic intertidal marshes and mudflats. Estuar Coast Shelf Sci 92:629-638

Fanjul E, Escapa M, Montemayor D, Addino M, Alvarez MF, Grela MA. Iribarne O (2015) Effect of crab bioturbation on organic matter processing in South West Atlantic intertidal sediments. J Sea Res 95:206-216

Gilbertson WW, Solan M, Prosser JI (2012) Differential effects of microorganism-invertebrate interactions on benthic nitrogen cycling. FEMS Microbiol Ecol 82:11-22

Glud RN, Ramsing NB, Revsbech NP (1992) Photosynthesis and photosynthesis coupled respiration in natural biofilms quantified with oxygen microsensors1. J Phycol 28: $51-60$
González Trilla G, De Marco S, Marcovecchio J, Vicari R, Kandus P (2010) Net primary productivity of Spartina densiflora Brong in an SW Atlantic coastal salt marsh. Estuaries Coasts 33:953-962

Guarrera S, Malacalza L, Lopez F (1972) Fitoplancton de las aguas superficiales de la provincia de Buenos Aires. Complejo Lagunar Salada Grande, Encadenadas del oeste y Encadenadas del sur. Rev Mus La Plata 12: $161-219$

*Halperin J, Ansaldo M, Pellerano GN, Luquet CM (2000) Bimodal breathing in the estuarine crab Chasmagnathus granulatus Dana 1851 - physiological and morphological studies. Comp Biochem Physiol A Mol Integr Physiol 126:341-349

Heip CHR, Goosen NK, Herman PMJ, Kromkamp JC, Middelburg JJ, Soetaert K (1995) Production and consumption of biological particles in temperate tidal estuaries. Oceanogr Mar Biol Annu Rev 33:1-149

* Hillebrand H, Kahlert M (2002) Effect of grazing and water column nutrient supply on biomass and nutrient content of sediment microalgae. Aquat Bot 72:143-159

Hindák F (1990) Studies on the chlorococcal algae (Chlorophyceae). V. Biol Práce 36:1-227

*Hughes RG (1999) Saltmarsh erosion and management of saltmarsh restoration; the effects of infaunal invertebrates. Aquat Conserv 9:83-95

Iribarne O, Botto $F$ (1998) Orientation of the extant stout razor clam Tagelus plebeius in relation to current direction: its paleoecological implication. J Shellfish Res 17: 165-168

Iribarne O, Bortolus A, Botto F (1997) Between-habitat differences in burrow characteristics and trophic modes in the southwestern Atlantic burrowing crab Chasmagnathus granulata. Mar Ecol Prog Ser 155:137-145

* Iribarne O, Bruschetti M, Escapa M, Bava J and others (2005) Small- and large-scale effect of the SW Atlantic burrowing crab Chasmagnathus granulatus on habitat use by migratory shorebirds. J Exp Mar Biol Ecol 315: $87-101$

Janousek CN (2009) Taxonomic composition and diversity of microphytobenthos in southern California marine wetland habitats. Wetlands 29:163-175

Jeffrey SW, Humphrey GF (1975) New spectrophotometric equations for determining chlorophylls $a, b, c_{1}$ and $c_{2}$ in higher plants, algae and natural phytoplankton. Biochem Physiol Pflanz 167:191-194

Jesus B, Brotas V, Marani M, Paterson DM (2005) Spatial dynamics of microphytobenthos determined by PAM fluorescence. Estuar Coast Shelf Sci 65:30-42

Jones CG, Lawton JH, Shachak M (1996) Organisms as ecosystem engineers. In: Samson FB, Knopf FL (eds) Ecosystem management: selected readings. Springer, New York, NY, p 130-147

Komárek J, Anagnostidis K (1985) Modern approach to the classification system of Cyanophytes. 2- Chroococcales. Arch Hydrobiol (Suppl) 73:157-226

Komárek J, Anagnostidis K (1989) Modern approach to the classification system of Cyanophytes. 4- Nostocales. Arch Hydrobiol (Suppl) 56:247-345

Komárek J, Anagnostidis K (1999) Süßwasserflora von Mitteleuropa. Cyanoprokaryota. 1. Teil: Chroococcales. Gustav Fischer Verlag, Jena

Komárek J, Anagnostidis K (2005) Süßwasserflora von Mitteleuropa. Cyanoprokaryota. 2. Teil: Oscillatoriales. Elsevier, München 
Kristensen E (2001) Impact of polychaetes (Nereis spp. and Arenicola marina) on carbon biogeochemistry in coastal marine sediments. Geochem Trans 2:92-103

Kristensen E (2007) Carbon balance in mangrove sediments: the driving processes and their controls. In: Tateda Y, Upstill-Goddard R, Goreau T, Alongi D, Nose A, Kristensen E, G. Wattayakorn G (eds) Greenhouse gas and carbon balances in mangrove coastal ecosystems. Gendai Tosho, Kanagawa, p 61-78

Kristensen E (2008) Mangrove crabs as ecosystem engineers; with emphasis on sediment processes. J Sea Res 59:30-43

Kristensen E, Penha-Lopes G, Delefosse M, Valdemarsen T, Quintana CO, Banta GT (2012) What is bioturbation? The need for a precise definition for fauna in aquatic sciences. Mar Ecol Prog Ser 446:285-302

Laverock B, Gilbert JA, Tait K, Osborn AM, Widdicombe S (2011) Bioturbation: impact on the marine nitrogen cycle. Biochem Soc Trans 39:315-320

Li B, Keesing JK, Lourey M, McLaughlin J (2013) Feeding and bioturbation effects of the sand dollar Peronella lesueuri (L. Agassiz, 1841) (Echinodermata) on microphytobenthos and sediment fluxes. Mar Freshw Behav Physiol 46:431-446

*ohrer AM, Thrush SF, Gibbs MM (2004) Bioturbators enhance ecosystem function through complex biogeochemical interactions. Nature 431:1092-1095

* Lohrer AM, Halliday NJ, Thrush SF, Hewitt JE, Rodil IF (2010) Ecosystem functioning in a disturbance-recovery context: contribution of macrofauna to primary production and nutrient release on intertidal sandflats. J Exp Mar Biol Ecol 390:6-13

Lorenzen CJ (1967) Determination of chlorophyll and pheopigments: spectrophotometric equations. Limnol Oceanogr 12:343-346

Luppi TA, Spivak ED, Anger K, Valero JL (2002) Patterns and processes of Chasmagnathus granulata and Cyrtograpsus angulatus (Brachyura: Grapsidae) recruitment in Mar Chiquita coastal lagoon, Argentina. Estuar Coast Shelf Sci 55:287-297

Luppi T, Bas C, Casariego AM, Albano M and others (2013) The influence of habitat, season and tidal regime in the activity of the intertidal crab Neohelice (= Chasmagnathus) granulata. Helgol Mar Res 67:1-15

* MacIntyre HL, Geider RJ, Miller DC (1996) Microphytobenthos: the ecological role of the 'secret garden' of unvegetated, shallow-water marine habitats. I. Distribution, abundance and primary production. Estuaries 19:186-201

MacTavish T, Stenton-Dozey J, Vopel K, Savage C (2012) Deposit-feeding sea cucumbers enhance mineralization and nutrient cycling in organically-enriched coastal sediments. PLOS ONE 7:e50031

Martinetto P, Iribarne O, Palomo G (2005) Effect of fish predation on intertidal benthic fauna is modified by crab bioturbation. J Exp Mar Biol Ecol 318:71-84

McAlice B (1971) Phytoplankton sampling with the Sedgwick-Rafter cell. Limnol Oceanogr 16:19-28

* Mendez Casariego A, Luppi T, Iribarne O, Daleo P (2011) Increase of organic matter transport between marshes and tidal flats by the burrowing crab Neohelice (Chasmagnathus) granulata Dana in SW Atlantic salt marshes. J Exp Mar Biol Ecol 401:110-117

Mermillod-Blondin F, Rosenberg R (2006) Ecosystem engineering: the impact of bioturbation on biogeochemical processes in marine and freshwater benthic habitats.
Aquat Sci 68:434-442

*Middelburg JJ, Barranguet C, Boschker HTS, Herman PMJ, Moens T, Heip CHR (2000) The fate of intertidal microphytobenthos carbon: an in situ ${ }^{13} \mathrm{C}$-labeling study. Limnol Oceanogr 45:1224-1234

Morrisey DJ (1988) Differences in effects of grazing by deposit-feeders Hydrobia ulvae (Pennant) (Gastropoda: Prosobranchia) and Corophium arenarium Crawford (Amphipoda) on sediment microalgal populations. II. Quantitative effects. J Exp Mar Biol Ecol 118:43-53

Mouget JL, Perkins R, Consalvey M, Lefebvre S (2008) Migration or photoacclimation to prevent high irradiance and UV-B damage in marine microphytobenthic communities. Aquat Microb Ecol 52:223-232

Needham HR, Pilditch CA, Lohrer AM, Thrush SF (2011) Context-specific bioturbation mediates changes to ecosystem functioning. Ecosystems 14:1096-1109

*Needham HR, Pilditch CA, Lohrer AM, Thrush SF (2013) Density and habitat dependent effects of crab burrows on sediment erodibility. J Sea Res 76:94-104

Nilsson C, Sundbäck K (1996) Amino acid uptake in natural microphytobenthic assemblages studied by microautoradiography. Hydrobiologia 332:119-129

Nuñez JD, Ribeiro PD, Ocampo EH, Luppi TA (2018) Neohelice granulata burrow fidelity behaviour related to landscape heterogeneity. Helgol Mar Res 72:17

* Pan J, Bournod CN, Cuadrado DG, Vitale A, Piccolo MC (2013) Interaction between estuarine microphytobenthos and physical forcings: the role of atmospheric and sedimentary factors. Int J Geosci 04:352

Paterson DM, Hagerthey SE (2001) Microphytobenthos in contrasting coastal ecosystems: biology and dynamics. In: Reise K (ed) Ecological comparisons of sedimentary shores. Ecological Studies (Analysis and Synthesis), Vol 151. Springer, Berlin, p 105-125

Perillo GME (1995) Definitions and geomorphologic classifications of estuaries. In: Perillo GME (ed) Developments in sedimentology. Geomorphology and sedimentology of estuaries. Elsevier, Amsterdam, p 17-47

Prescott GW (1951) Algae of the Western Great Lakes area. W.M.C. Brown Co Publications, Dubuque, IA

Prygiel J, Coste M (2000) Guide méthodologique pour la mise en oeuvre de l'Indice biologique diatomées NF T 90-354. Agences de l'Eau-cemagref-groupement de Bordeaux. Agences de l'Eau, Cemagref, Bordeaux

* Queirós AM, Stephens N, Cook R, Ravaglioli C and others (2015) Can benthic community structure be used to predict the process of bioturbation in real ecosystems? Prog Oceanogr 137:559-569

Reta R, Martos P, Perillo GME, Piccolo CM, Ferrante A (2001) Características hidrográficas del estuario de la Laguna de Mar Chiquita. In: Iribarne OO (ed) Reserva de biósfera Mar Chiquita: características físicas, biológicas y ecológicas. Editorial Martin, Mar del Plata, p 31-52

* Revsbech NP, Jorgensen BB (1983) Photosynthesis of benthic microflora measured with high spatial resolution by the oxygen microprofile method: capabilities and limitations of the method. Limnol Oceanogr 28:749-756

Round FE (1965) The epipsammon; a relatively unknown freshwater algal association. Br Phycol Bull 2:456-462

Sandwell DR, Pilditch CA, Lohrer AM (2009) Density dependent effects of an infaunal suspension-feeding bivalve (Austrovenus stutchburyi) on sandflat nutrient fluxes and microphytobenthic productivity. J Exp Mar Biol Ecol 373:16-25 
Serôdio J (2004) Analysis of variable chlorophyll fluorescence in microphytobenthos assemblages: implications of the use of depth-integrated measurements. Aquat Microb Ecol 36:137-152

Serôdio J, Vieira S, Cruz S (2008) Photosynthetic activity, photoprotection and photoinhibition in intertidal microphytobenthos as studied in situ using variable chlorophyll fluorescence. Cont Shelf Res 28:1363-1375

Spivak E, Anger K, Luppi T, Bas C, Ismael D (1994) Distribution and habitat preferences of two grapsid crab species in Mar Chiquita Lagoon (Province of Buenos Aires, Argentina). Helgol Meeresunters 48:59

Stal LJ (1994) Microbial mats in coastal environments. In: Stal LJ, Caumette P (eds) Microbial mats. NATO ASI Series. Springer, Berlin, p 21-32

Stal LJ (2010) Microphytobenthos as a biogeomorphological force in intertidal sediment stabilization. Ecol Eng 36: 236-245

Strickland JDH, Parsons TR (1972) A practical handbook of seawater analysis, $2^{\text {nd }}$ edn. Bull Fish Res Board Can 167: $1-310$

Stutes AL, Cebrian J, Corcoran AA (2006) Effects of nutrient enrichment and shading on sediment primary production and metabolism in eutrophic estuaries. Mar Ecol Prog Ser 312:29-43

Sundbäck K, Linares F, Larson F, Wulff A, Engelsen A (2004) Benthic nitrogen fluxes along a depth gradient in a microtidal fjord: the role of denitrification and microphytobenthos. Limnol Oceanogr 49:1095-1107

Teal LR, Parker ER, Solan M (2013) Coupling bioturbation activity to metal (Fe and $\mathrm{Mn}$ ) profiles in situ. Biogeosciences 10:2365-2378

Tell G, Conforti V (1986) Euglenophyta pigmentadas de la Argentina. J. Cramer in der Gebrüder Borntraeger Verlagsbuchhandlung, Berlin

Thrush SF, Hewitt JE, Kraan C, Lohrer AM, Pilditch CA, Douglas E (2017) Changes in the location of biodiversityecosystem function hot spots across the seafloor landscape with increasing sediment nutrient loading. Proc $\mathrm{R}$ Soc B 284:20162861

Editorial responsibility: Stephen Wing, Dunedin, New Zealand
Tilman D (1999) Promoting the science of ecology. Ecology 80:1455-1474

Underwood GJC (2001) Microphytobenthos. In: Steele JH, Thorpe SA, Turekian KK (eds) Encyclopedia of ocean sciences. Elsevier, Amsterdam, p 1770-1777

Underwood GJC, Kromkamp J (1999) Primary production by phytoplankton and microphytobenthos in estuaries. Adv Ecol Res 29:93-153

Underwood G, Provot L (2000) Determining the environmental preferences of four estuarine epipelic diatom taxa: growth across a range of salinity, nitrate and ammonium conditions. Eur J Phycol 35:173-182

Underwood GJC, Perkins RG, Consalvey MC, Hanlon ARM, Oxborough K, Baker NR, Paterson DM (2005) Patterns in microphytobenthic primary productivity: species-specific variation in migratory rhythms and photosynthetic efficiency in mixed-species biofilms. Limnol Oceanogr 50:755-767

Volkenborn N, Hedtkamp SIC, van Beusekom JEE, Reise K (2007) Effects of bioturbation and bioirrigation by lugworms (Arenicola marina) on physical and chemical sediment properties and implications for intertidal habitat succession. Estuar Coast Shelf Sci 74:331-343

Waldbusser GG, Marinelli RL, Whitlatch RB, Visscher PT (2004) The effects of infaunal biodiversity on biogeochemistry of coastal marine sediments. Limnol Oceanogr 49:1482-1492

*Wang JQ, Zhang XD, Jiang LF, Bertness MD and others (2010) Bioturbation of burrowing crabs promotes sediment turnover and carbon and nitrogen movements in an estuarine salt marsh. Ecosystems 13:586-599

*Webb AP, Eyre BD (2004) The effect of natural populations of the burrowing and grazing soldier crab (Mictyris longicarpus) on sediment irrigation, benthic metabolism and nitrogen fluxes. J Exp Mar Biol Ecol 309:1-19

*Wulff A, Zacher K, Hanelt D, Al-Handal A, Wiencke C (2008) UV radiation a threat to Antarctic benthic marine diatoms? Antarct Sci 20:13-20

Zar JH (1999) Biostatistical analysis, $4^{\text {th }}$ edn. Prentice Hall, Englewood Cliffs, NJ

Submitted: June 12, 2019; Accepted: September 5, 2019 Proofs received from author(s): November 28, 2019 